\title{
A review of hydrogeology and water resources on the Isle of Wight
}

\author{
L Maurice $^{1^{*}}$, M. Packman ${ }^{2}$ and P Shaw ${ }^{3}$ \\ ${ }^{1}$ British Geological Survey, Maclean Building, Wallingford, Oxfordshire, \\ OX10 8BB, United Kingdom \\ ${ }^{2}$ Southern Water Southern Water, 249 Fairlee Road, Newport, Isle of Wight, PO30 2JU, \\ United Kingdom \\ ${ }^{3}$ Environment Agency, Guildbourne House, Chatsworth Road, Worthing, West Sussex, \\ BN11 1LD, United Kingdom \\ *Corresponding author (e mail: loma@bgs.ac.uk)
}

\begin{abstract}
The Isle of Wight is a small, heavily populated island, where complex and careful management is required to ensure sustainable use of water resources. Much of the island is underlain by permeable strata and groundwater is an important source of supply. Many groundwater studies were undertaken by the water provider and regulatory authority from the 1970's onwards, but this work is not publically available. This paper reviews these previous studies and provides an overview of the hydrogeology of the island with particular focus on the Lower Greensand Group and the Chalk/Upper Greensand aquifer. As one of the areas in the UK to experience water shortages during the 1976 drought, the Isle of Wight became the focus for new strategies for the sustainable development of water, which included the exploitation of more marginal aquifers, water metering and an engineering solution to provide water from the mainland. Ensuring future water demand is managed sustainably in an area where aquifers are fully exploited is likely to rely on the twin track approach of both further demand-management and unconventional water resource development, such as wastewater re-use or desalination.
\end{abstract}

